\title{
H4 histamine receptors inhibit steroidogenesis and proliferation in Leydig cells
}

\author{
Adriana María Belén Abiuso', Esperanza Berensztein ${ }^{2}$, Romina María Pagotto ${ }^{1,3}$, \\ Elba Nora Pereyra', Vanina Medina ${ }^{4,5}$, Diego José Martinel Lamas ${ }^{4,5}$, \\ Marcos Besio Moreno', Omar Pedro Pignataro ${ }^{1,6}$ and Carolina Mondillo'
}

1'Laboratory of Molecular Endocrinology and Signal Transduction, Institute of Biology and Experimental Medicine, National Scientific and Technical Research Council (IByME-CONICET), CP 1428 Buenos Aires, Argentina ${ }^{2}$ Research Laboratory, Endocrinology Service, Garrahan Pediatric Hospital, CP 1245 Buenos Aires, Argentina

${ }^{3}$ Cell Biology Unit, Institut Pasteur de Montevideo, CP 11400 Montevideo, Uruguay

${ }^{4}$ Laboratory of Radioisotopes, School of Pharmacy and Biochemistry, University of Buenos Aires, CP 1113 Buenos Aires, Argentina

${ }^{5}$ Institute for Biomedical Research (BIOMED), School of Medical Sciences, Pontifical Catholic University of Argentina, National Scientific and Technical Research Council (UCA-CONICET), CP1107 Buenos Aires, Argentina ${ }^{6}$ Department of Biological Chemistry, School of Sciences, University of Buenos Aires, CP 1428 Buenos Aires, Argentina

Correspondence should be addressed to C Mondillo Email carolina.mondillo@gmail.com

\begin{abstract}
The histamine $\mathrm{H} 4$ receptor $(\mathrm{HRH} 4)$, discovered only 13 years ago, is considered a promising drug target for allergy, inflammation, autoimmune disorders and cancer, as reflected by a steadily growing number of scientific publications and patent applications. Although the presence of HRH4 has been evidenced in the testis, its specific localization or its role has not been established. Herein, we sought to identify the possible involvement of HRH4 in the regulation of Leydig cell function. We first evaluated its expression in MA-10 Leydig tumor cells and then assessed the effects of two HRH4 agonists on steroidogenesis and proliferation. We found that HRH4 is functionally expressed in MA-10 cells, and that its activation leads to the inhibition of LH/human chorionic gonadotropin-induced CAMP production and StAR protein expression. Furthermore, we observed decreased cell proliferation after a 24-h HRH4 agonist treatment. We then detected for the sites of $\mathrm{HRH} 4$ expression in the normal rat testis, and detected HRH4 immunostaining in the Leydig cells of rats aged 7-240 days, while 21-day-old rats also presented $\mathrm{HRH} 4$ expression in male gametes. Finally, we evaluated the effect of HRH4 activation on the proliferation of normal progenitor and immature rat Leydig cell culture, and both proved to be susceptible to the anti-proliferative effect of HRH4 agonists. Given the importance of histamine (2-(1H-imidazol-4-yl)ethanamine) in human (patho)physiology, continued efforts are directed at elucidating the emerging properties of $\mathrm{HRH} 4$ and its ligands. This study reveals new sites of HRH4 expression, and should be considered in the design of selective HRH4 agonists for therapeutic purposes.
\end{abstract}
Key Words
- H4 receptors
- histamine
- steroidogenesis
- Leydig cells

Journal of Endocrinology (2014) 223, 241-253 http://joe.endocrinology-journals.org DOI: 10.1530/JOE-14-0401
(C) 2014 Society for Endocrinology Printed in Great Britain
Published by Bioscientifica Ltd. 


\section{Introduction}

Histamine (2-(1H-imidazol-4-yl)ethanamine; HA) is an endogenous biogenic amine synthesized from L-histidine exclusively through the catalytic activity of histidine decarboxylase (HDC), an enzyme that is widely distributed throughout the body (Ohtsu 2010). Since its discovery at the beginning of the 20th century (Dale \& Laidlaw 1910), HA has been one of the most studied biological molecules in medicine (Parsons \& Ganellin 2006). It is now known to elicit a vast spectrum of physiological and pathological actions through binding to four $G$ protein-coupled receptors, designated as $\mathrm{H} 1, \mathrm{H} 2, \mathrm{H} 3$, and $\mathrm{H} 4$ (histamine $\mathrm{H} 1$ receptor (HRH1)-HRH4), that are differentially expressed in various cell types (Akdis \& Simons 2006, Parsons \& Ganellin 2006, Bongers et al. 2010, Shahid et al. 2011).

HA-synthesizing mast cells and $\mathrm{HA}$ receptors are present in the diverse compartments of the testis in several species, including human: HRH1 and HRH2 have been detected in germ and peritubular cells, as well as in macrophages and Leydig cells (Albrecht et al. 2005, Mondillo et al. 2005, 2007, Khan \& Rai 2007), and HRH1 has also been found in the testicular capsule (Nemetallah et al. 1983). Accordingly, numerous studies from our group and others over the past few years have documented the ability of HA to modulate Leydig cell steroidogenesis through HRH1 and HRH2 (Mayerhofer et al. 1989, Mondillo et al. 2005, 2007, 2009, Khan \& Rai 2007), and a very recent publication from our group has suggested a role for HA as an autocrine-paracrine regulator of Leydig cell proliferation under testicular pathological conditions (Pagotto et al. 2012). Considering that germ cells express HDC (Safina et al. 2002), and that HA has been implicated in spermatogenesis, penile erection and sexual behavior as well as steroidogenesis (Cara et al. 1995, Par et al. 2003, Sinha et al. 2006), it appears that the amine plays an integral role in the regulation of male reproductive function, which certainly deserves further investigation.

HRH4 is the newest member of the HA receptor family, discovered about 13 years ago (Morse et al. 2001, Nguyen et al. 2001). It is considered a promising drug target for allergy, inflammation, autoimmune disorders, and cancer, as reflected by a steadily growing number of scientific publications and patent applications (Schreeb et al. 2013). The current knowledge about the expression and function of HRH4 within the testis is far from complete. In this regard, there is an evidence of its presence but neither its specific localization nor its role has been established (Nguyen et al. 2001, O'Reilly et al. 2002). Herein, we sought to identify the possible involvement of HRH4 in the regulation of Leydig cell function. Using MA-10 mouse Leydig tumor cells (that possess many characteristics of normal Leydig cells including low levels of luteinizing hormone (LH) receptors, as well as functional receptors HRH1 and HRH2) as an experimental model, we first carried out immunofluorescence studies to evaluate the expression of HRH4, and then assessed the effects of two different HRH4 agonists on steroidogenesis and proliferation. We found that HRH4 is functionally expressed in MA-10 Leydig cells, and that its activation leads to inhibition of biochemical steps involved in LH/human chorionic gonadotropin (hCG) steroidogenic action, namely cAMP production and stimulation of StAR protein expression. Also, we observed that HRH4 agonist treatment inhibits MA-10 cell proliferation. Given the tumor origin of MA-10 cells, we then searched for HRH4 expression sites in the normal rat testis and detected HRH4 immunostaining in Leydig cells of rats aged 7-240 days, while 21-day-old rats also presented HRH4 expression within the seminiferous tubules, in male gametes. Finally, we assessed the effect of HRH4 activation on the proliferation of normal progenitor and immature rat Leydig cells in culture, and both proved to be susceptible to the anti-proliferative effect of HRH4 agonists. All in all, this study reveals new sites of functional HRH4 expression, and should be taken into consideration in the rational design of selective HRH4 agonists for therapeutic purposes.

\section{Materials and methods}

\section{Materials}

Purified hCG (CR-127; $14900 \mathrm{IU} / \mathrm{mg}$ ) was a gift from the National Hormone and Pituitary Program, National Institute of Diabetes and Digestive and Kidney Diseases (NIDDK), National Institutes of Health (NIH). $\left[{ }^{3} \mathrm{H}\right]$-thymidine $(20 \mathrm{Ci} / \mathrm{mmol})$ and $\mathrm{Na}^{125} \mathrm{I}(600 \mathrm{Ci} / \mathrm{mmol})$ were purchased from New England Nuclear Corporation (North Billerica, MA, USA). The following chemicals were purchased from Sigma-Aldrich Chemical Co.: VUF 8430 (VUF), 20-O-monosuccinyladenosine-3',5'-cyclic monophosphate tyrosyl methyl ester (TME-cAMP), dibutyryl adenosine $3^{\prime}, 5^{\prime}$ cyclic monophosphate (db-cAMP), HEPES, phenylmethylsulfonyl fluoride (PMSF), sodium orthovanadate, leupeptin, aprotinin, pepstatin A, spermidine, spermine, sodium fluoride $(\mathrm{NaF})$, and mouse monoclonal anti- $\beta$-tubulin antibody. JNJ 28610244 (JNJ286), JNJ7777120 (JNJ77), R- $\alpha$-methylhistamine (R- $\alpha$ ), Clobenpropit (CLOB), and rabbit anti-HRH4 primary antibody were a generous gift

Published by Bioscientifica Ltd 
from Dr Elena Rivera (Laboratory of Radioisotopes, School of Pharmacy and Biochemistry, University of Buenos Aires). Collagenase type II (CLS-2; 125 IU/mg) was from Worthington Biochemical Corporation (Lakewood, CA, USA) Cell culture supplies were obtained from Gibco-BRL, and plasticware was obtained from Corning (Tewksbury, MA, USA) and BD Biosciences (Franklin Lakes, NJ, USA). TMEcAMP was radiolabeled with $\mathrm{Na}^{125}$ I in our laboratory by the method of chloramine-T as described by Piroli et al. (1992). The specific antibody for cAMP was provided by Dr A F Parlow (National Hormone and Pituitary Program, NIDDK). Dr Walter L Miller (University of California, San Francisco) and Dr Marta Tesone (Ovarian Physiology Laboratory, Institute of Biology and Experimental Medicine, Buenos Aires, Argentina) generously provided StAR protein antibody. Goat polyclonal anti-HRH4 primary antibody was commercially obtained from Santa Cruz Biotechnology. Peroxidase-labeled goat anti-rabbit IgG, peroxidase-labeled horse anti-mouse IgG, horse anti-goat IgG-FITC, and goat anti-rabbit IgG-FITC were purchased from Vector Laboratories (Burlingame, CA, USA). Other reagents used were of the best grade available and were obtained from commonly used suppliers.

\section{Culture of MA-10 Leydig tumor cells}

The MA-10 mouse Leydig tumor cell line (Ascoli 1981), generously given to O P P by Dr Mario Ascoli (University of Iowa, Iowa City, IA, USA), were grown in DMEM/Ham F-12 (DMEM/F12) containing $4.76 \mathrm{~g} / 1$ of HEPES, $1.2 \mathrm{~g} / 1$ of sodium bicarbonate, $1 \mathrm{ml} / 1$ of Gentamicin Reagent Solution (Gibco, Invitrogen), and 15\% horse serum (growth medium) at $37^{\circ} \mathrm{C}$ in a $5 \% \mathrm{CO}_{2}$ atmosphere, as previously described (Mondillo et al. 2005, 2009, Pagotto et al. 2012). All experiments described herein were carried out in triplicate, with at least three different cell line batches or passage numbers $(<20)$ of cells, and similar results were obtained each time.

\section{Preparation of progenitor and immature rat Leydig cells}

The progenitor and immature Leydig cells were isolated from a pool of 16 testes obtained from eight SpragueDawley rats (aged 18-20 and 35 days respectively, Charles River descendants, Animal Care Laboratory, Institute of Biology and Experimental Medicine) by collagenase dispersion and Percoll gradient centrifugation as previously described (Pagotto et al. 2012). The procedures used were approved by the Institutional Animal Care and Use Committee (Institute of Biology and Experimental
Medicine-CONICET), which follows NIH guidelines. The purity of Leydig cells obtained was $>91 \%$ as assessed by histochemical staining for 3 $\beta$-hydroxysteroid dehydrogenase activity. All experiments were repeated with at least three different preparations of Leydig cells obtained from different sets of animals. The concentration of hCG or insulin-like growth factor 1 (IGF1) used (100 ng/ml) was chosen empirically, as the lowest concentrations elicit a maximal proliferative effect (data not shown).

\section{Immunocytochemistry for detection of HRH4 in MA-10 cells}

HRH4 immunocytochemistry was performed on MA-10 cells as follows: the cells were seeded onto glass coverslips (12 mm diameter; Marienfeld, Lauda-Königshofen, Germany) at a density of 80000 cells/well in 12-well plates, and cultured in $1 \mathrm{ml}$ of DMEM/F12 (supplemented with $15 \%$ horse serum) at $37^{\circ} \mathrm{C}$ in a humidified atmosphere containing $5 \% \mathrm{CO}_{2}$. On the third day, the cells were washed, fixed in $4 \%$ formaldehyde in PBS for $10 \mathrm{~min}$, and then washed extensively in PBS. Next, the cells were permeabilized with $0.25 \%$ Triton X-100 in PBS for $10 \mathrm{~min}$, and again washed extensively with PBS. The immunostaining was carried out as described below.

\section{Immunofluorescence}

The cells were blocked for $60 \mathrm{~min}$ in $10 \mathrm{mM}$ PBS containing 1\% BSA (blocking solution). The primary antibody, goat anti-HRH4 antibody (1:50 in blocking solution; Santa Cruz Biotechnology, Santa Cruz, CA, USA), or rabbit anti-HRH4 antibody (1: 50 in blocking solution, Millipore, Temecula, CA, USA) was added and incubated overnight at $4{ }^{\circ} \mathrm{C}$. For negative controls, PBS was used instead of primary antibodies. The cells were then washed and incubated with horse anti-goat IgG-FITC or goat anti-rabbit IgG-FITC (Vector Laboratories) for $30 \mathrm{~min}$ at room temperature. The cell nuclei were counterstained with 4',6-diamidino-2-phenylindole (DAPI; 1/10 000 in PBS). After washing, cells were mounted in the Vectashield medium (Vector Laboratories) and observed under a laser confocal microscope (Nikon C1).

\section{Quantification of progesterone levels}

The cells were plated in 24-well plates on day 0 at a density of $1.25 \times 10^{5}$ cells/well, and in a total volume of $1 \mathrm{ml}$ of the growth medium (DMEM/F12 containing $4.76 \mathrm{~g} / \mathrm{l}$ of HEPES, $1.2 \mathrm{~g} / 1$ of sodium bicarbonate, $1 \mathrm{ml} / 1$ of

Published by Bioscientifica Ltd. 
Gentamicin Reagent Solution (Gibco, Invitrogen), and $15 \%$ horse serum). They were maintained in a humidified atmosphere containing $5 \% \mathrm{CO}_{2}$, and were used on day 3 . At this time, the cell density was $\sim 5 \times 10^{5}$ cells/well. On this day, the cells were washed twice with $1 \mathrm{ml}$ of warm serumfree medium supplemented with $1 \mathrm{mg} / \mathrm{ml}$ of BSA (assay medium). A total volume of $0.5 \mathrm{ml}$ assay medium was incubated at $37^{\circ} \mathrm{C}$ with the corresponding additions as shown in each figure. After $5 \mathrm{~h}$, the media were removed and progesterone was measured by RIA, as described previously (Mondillo et al. 2009). The interassay coefficients of variation $(\mathrm{CV})$ and intraassay $\mathrm{CV}$ were $<14 \%$.

\section{Determination of intracellular cAMP in MA-10 Leydig cells}

The methodology for evaluating intracellular cAMP in the MA-10 cell line has been previously published (Mondillo et al. 2005). After a 20-min incubation of the cells in the presence of the corresponding additions, the plates were placed on ice and the medium was aspirated. Then, $0.5 \mathrm{ml}$ of cold distilled water was added to each well, and the cells were scraped and disrupted by ultrasonic oscillation. The samples were heated for three periods of $1 \mathrm{~min}$ in boiling water to destroy endogenous protein kinase. Then the samples were centrifuged in an Eppendorf microfuge (Brinkmann Instruments, Westbury, NY, USA) for $3 \mathrm{~min}$, the samples were diluted using $50 \mathrm{mM}$ sodium acetate buffer ( $\mathrm{pH}$ 6.0). Unknown samples and standards were acetylated and assayed by RIA using the protocol described by Steiner et al. (1969) and modified as follows (Piroli et al. 1992): at the end of the incubation period, the antigenantibody complexes were precipitated by the addition of $50 \mathrm{ml}$ of $2 \%$ BSA and $2 \mathrm{ml}$ of cold ethanol (95\%), and centrifuged at $2000 \boldsymbol{g}$ for $20 \mathrm{~min}$. The supernatants were then aspirated, and radioactivity of the pellets was determined in a Packard Auto-Gamma counter (Packard Instrument Co., Downers Grove, IL, USA). The interassay $\mathrm{CV}$ and intraassay $\mathrm{CV}$ were $<10 \%$.

\section{Western blotting analysis and immunodetection of proteins}

Total cellular protein was obtained by placing MA-10 cells in the lysis buffer (10 mM Tris-HCl $(\mathrm{pH} 8), 1 \%$ Triton $\mathrm{X}-100$, and $0.5 \mathrm{mM}$ EDTA) containing a protease inhibitor cocktail $(5 \mu \mathrm{g} / \mathrm{ml}$ of leupeptin, $5 \mu \mathrm{g} / \mathrm{ml}$ of pepstatin $\mathrm{A}$, $5 \mu \mathrm{g} / \mathrm{ml}$ of aprotinin, $25 \mathrm{mM} \mathrm{NaF}, 400 \mu \mathrm{M}$ PMSF, $0.15 \mathrm{mM}$ spermine, $0.5 \mathrm{mM}$ spermidine, and $25 \mathrm{mM}$ sodium orthovanadate), followed by a brief sonication (ten cycles of $10 \mathrm{~s}$ ). The total protein concentrations were measured using the Bradford assay (Bio-Rad Laboratories, Inc.). Equal amounts of protein per sample $(30-40 \mu \mathrm{g})$ were then boiled for $5 \mathrm{~min}$ in the sample buffer $(0.06 \mathrm{M}$ Tris$\mathrm{HCl}(\mathrm{pH} 6.8), 25 \% \mathrm{v} / \mathrm{v}$ glycerol, $2 \% \mathrm{w} / \mathrm{v}$ SDS, $0.01 \% \mathrm{w} / \mathrm{v}$ bromophenol blue, and $5 \% \mathrm{v} / \mathrm{v} \beta$-mercaptoethanol), subjected to SDS-PAGE, and transferred to nitrocellulose (Bio-Rad Laboratories). The membranes were blocked in $5 \%$ nonfat dried milk in PBS-T and incubated overnight with polyclonal anti-StAR antibody at $4{ }^{\circ} \mathrm{C}$. After three washes (10 $\mathrm{min}$ at room temperature) in PBS-T (PBS $+0.1 \%$ Tween-20), the membranes were subjected to a 2-h incubation with the appropriate secondary antibody. Detection was performed with ECL Plus Western Blotting Detection Reagents (Amersham, GE Healthcare BioSciences, Piscataway, NJ, USA). The intensity of immunospecific bands was quantified using ImageJ Software (National Institutes of Health, Bethesda, MA, USA; Abramoff et al. 2004). To correct for equal loading, the StAR blots were stripped and reprobed for $\beta$-tubulin.

\section{$\left[{ }^{3} \mathrm{H}\right]$-thymidine incorporation into DNA}

The cell proliferation was assessed as a function of $\left[{ }^{3} \mathrm{H}\right]-$ thymidine incorporation, as described previously (Garnier et al. 1993, Pagotto et al. 2012). MA-10 cells $\left(2.5 \times 10^{4}\right.$ cells/well) were seeded and cultured in 96-well plates for $24 \mathrm{~h}$, and then growth medium was replaced with starvation medium (serum-free medium). The cells were incubated in these conditions for $24 \mathrm{~h}$ and then treated with VUF or R- $\alpha$, as indicated in each figure. Twenty hours after the initiation of treatment, $\left[{ }^{3} \mathrm{H}\right]$-thymidine $(0.25 \mu \mathrm{Ci} / \mathrm{ml})$ was added, and the incubation was continued for another $4 \mathrm{~h}$. Progenitor or immature Leydig cells $(7 \times$ $10^{4} /$ well) were seeded and cultured in M199 containing $1.2 \mathrm{~g} / \mathrm{l}$ of $\mathrm{NaHCO}_{3}, 20 \mathrm{mM}$ HEPES, $1 \mathrm{ml} / \mathrm{l}$ Gentamicin Reagent Solution, and 0.5\% FBS in 96-well plates coated with gelatin for $18 \mathrm{~h}$, after which the medium was changed to a fresh medium and the cells were treated with hCG, IGF1, VUF, CLOB, and/or JNJ77 as shown in each figure. Eight hours after initiation of treatment, $\left[{ }^{3} \mathrm{H}\right]$-thymidine $(0.25 \mu \mathrm{Ci} / \mathrm{ml})$ was added, and the incubation was continued for another $16 \mathrm{~h}$. For all cell types (MA-10 cells, progenitor, and immature Leydig cells), each treatment was terminated by washing the cells twice with ice-cold PBS. Subsequently, the cells were trypsinized and harvested by vacuum aspiration onto the glass-fiber filters, which were washed, dried, and transferred to glass vials containing scintillation cocktail (Optiphase Hisafe III scintillation liquid; Wallac, Gaithersburg, MD, USA) for the measurement of radioactivity (Tri-carb 1600TR; Packard, Meriden, CT, USA).

Published by Bioscientifica Ltd. 
All data points are the average of three experiments, and each experiment was carried out in octuplicate.

\section{MTS assay}

The 3-(4,5-dimethylthiazol-2-yl)-5-(3-carboxymethoxyphenyl)-2-(4-sulfophenyl)-2H-tetrazolium (MTS) assay, a colorimetric method for determining viable (metabolically active) cells, was used to assess the proliferation of VUF-treated MA-10 cells compared with controls. The cell proliferation was determined spectrophotometrically by measuring the conversion of the MTS substrate to the formazan product, which is directly proportional to the number of viable cells. In brief, following treatment with the corresponding stimuli as described above, MTS reagent (20 $\mu \mathrm{l} /$ well; CellTitre 96 Aqueous One Solution Cell Proliferation Assay Kit; Promega Corporation) was added to control and treated cells, and the optical density (OD) at $490 \mathrm{~nm}$ was recorded after $1 \mathrm{~h}$ of incubation at $37^{\circ} \mathrm{C}$ using a microplate reader. Relative cell numbers were determined based on the OD of the samples. The blank values were subtracted from each well of the treated cells and controls; and the mean and s.E.M. for each treatment were calculated relative to the control as follows:

Percentage of viable cells $=\frac{A_{\mathrm{T}}-A_{\mathrm{B}}}{A_{\mathrm{C}}-A_{\mathrm{B}}} \times 100$

where $A_{\mathrm{C}}$, absorbance of control cells (mean value); $A_{\mathrm{T}}$, absorbance of treated cells (mean value), and $A_{\mathrm{B}}$, absorbance of blank wells (mean value).

\section{HRH4 immunoexpression in the rat testis}

Immunohistochemistry for HRH4 was performed on Bouin-fixed paraffin-embedded testis sections of rats aged 7, 21, 35, 90, and 240 days. The testis sections were incubated with a primary goat polyclonal antibody raised against HRH4 (1:50 in blocking solution, Santa Cruz, CA, USA). As a secondary antibody, a biotinylated donkey antigoat immunoglobin was used. Staining was performed using the streptavidin-biotin and peroxidase method, according to the manufacturer's protocol (DAKO Catalyzed Signal Amplification System, HRP, Dako Cytomation, Carpinteria, CA, USA). Human mammary tissue was used as a positive control (Medina et al. 2011). Immuno studies were repeated thrice, and no difference in the pattern of immunolocalization was detected between the three samples. As a negative control, normal goat serum was used instead of the primary antibody. No specific immunoreactivity was detected in these sections.

\section{Statistical analyses}

All experiments carried out herein were repeated at least three times, and the data were pooled. If heterogeneity of variance was detected by Bartlett test, this was reduced by logarithmic transformation of the data before analysis. These data were then subjected to one-way ANOVA followed by Newman-Keuls test for multiple-range comparisons. A value of $P<0.05$ was considered to be statistically significant.

\section{Results}

\section{Detection of HRH4 in MA-10 cells by immunofluorescence}

We first evaluated the expression of HRH4 in MA-10 cells by fluorescent immunodetection, employing two different specific anti-HRH4 antibodies, as described in 'Materials and methods' section. It is shown in Fig. 1 that strong HRH4 labeling was observed for both antibodies.

\section{Effect of HRH4 activation on MA-10 Leydig cell progesterone production}

MA-10 cells were incubated with increasing concentrations of the HRH4 agonist VUF $(1 \mathrm{nM}-10 \mu \mathrm{M})$, in the absence or presence of $40 \mathrm{ng} / \mathrm{ml} \mathrm{hCG}$, for $5 \mathrm{~h}$. While VUF had a modest stimulatory effect on basal steroid production, which was evident at $1 \mu \mathrm{M}$ onwards (Fig. 2A), it potently inhibited hCG-stimulated steroidogenesis

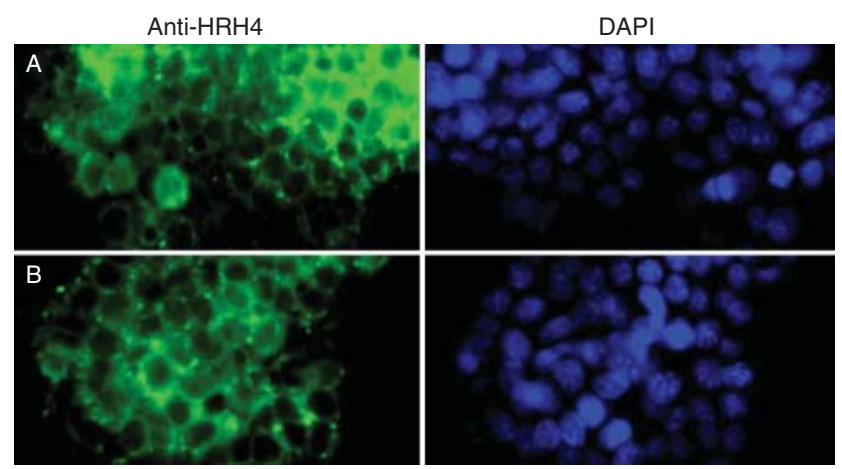

Figure 1

Confocal microscopy analysis of HRH4 expression in MA-10 cells. HRH4 staining was performed using rabbit anti-HRH4 antibody followed by FITC-labeled goat anti-rabbit IgG (green) (A), or goat anti-HRH4 antibody followed by FITC-labeled horse anti-goat IgG (green) (B). Cell nuclei were counterstained with DAPI (blue). Photographs were taken at $400 \times$ magnification. One representative experiment of three is shown. HRH4, histamine receptor subtype 4; DAPI, 4',6-diamidino-2-phenylindole. A full colour version of this figure is available via http://dx.doi.org/10.1530/ JOE-14-0401.

Published by Bioscientifica Ltd. 

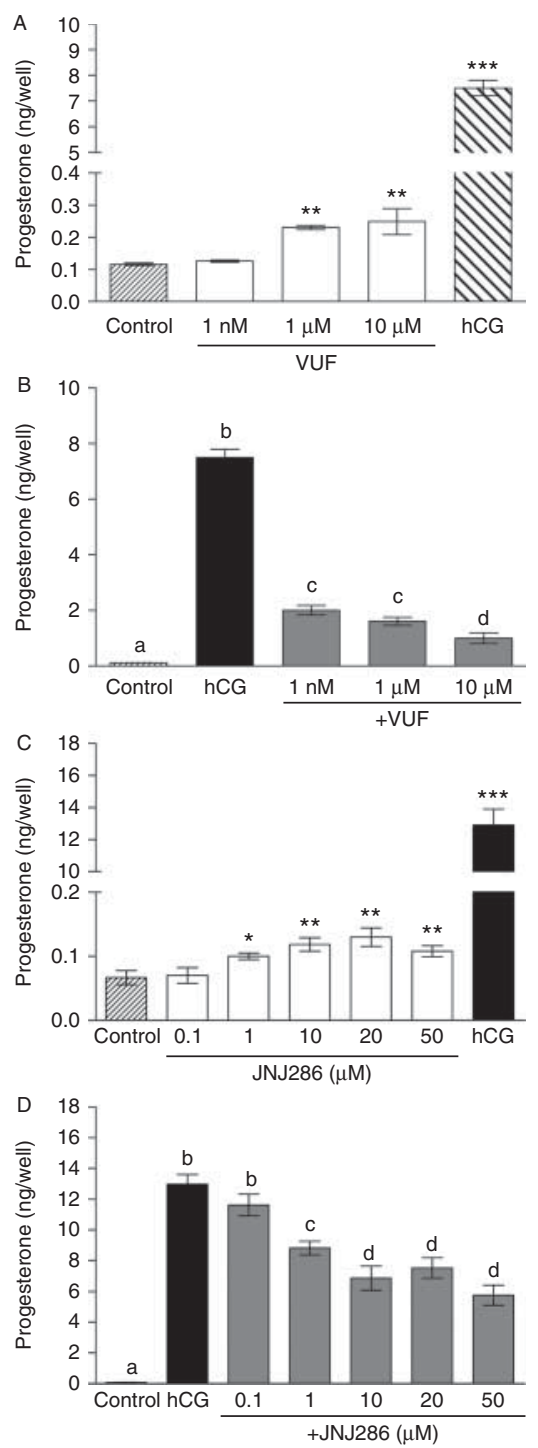

Figure 2

Effect of HRH4 agonists on basal and hCG-stimulated progesterone production in MA-10 cells. The cells were incubated with increasing concentrations of VUF, in the absence (A) or presence (B) of $40 \mathrm{ng} / \mathrm{ml} \mathrm{hCG,}$ for $5 \mathrm{~h}$. Scale bars are means \pm s.E.M. for a representative $(n=3)$ triplicate experiment. $* * P<0.01$ vs Control and $* * * P<0.001$ vs Control. Different letters above the bars indicate that the groups differ significantly at $P<0.01$. In subsequent experiments, cells were incubated with increasing concentrations of JNJ286, in the absence (C) or presence (D) of $40 \mathrm{ng} / \mathrm{ml}$ hCG, for 5 h. Scale bars are means \pm s.E.M. for a representative $(n=3)$ triplicate experiment. ${ }^{*} P<0.05$ vs Control and $* * P<0.01$ vs Control. Different letters above the bars indicate that the groups differ significantly at $P<0.01$.

already at a concentration of $1 \mathrm{nM}$ (Fig. 2B, 78\% inhibition for $10 \mu \mathrm{M}$ VUF, on average). To complement these findings, we also evaluated the effect of JNJ286, another specific agonist of HRH4, on progesterone production. This second agonist appeared to be less effective than VUF, so we decided to extend the range of tested concentrations beyond $10 \mu \mathrm{M}(0.1-50 \mu \mathrm{M})$. Within this range of concentrations, JNJ286 exerted similar effects to those observed for VUF (Fig. 2C and D), although it still proved to be less potent (Fig. 2D, 56\% inhibition of hCG-stimulated progesterone production for $50 \mu \mathrm{M} \mathrm{JNJ} 286$, on average).

\section{Activation of HRH4 affects LH/hCG steroidogenic action at steps before and after CAMP production}

Considering that cAMP is the main second messenger in the LH/hCG signaling pathway, and the fact that HRH4 has been extensively described as a Gi-coupled receptor (Leurs et al. 2009, Medina \& Rivera 2010, Jemima et al. 2014), we first evaluated the capacity of VUF to negatively regulate cAMP production. MA-10 cells were incubated with or without 1 or $10 \mu \mathrm{M}$ VUF in the absence or presence of $40 \mathrm{ng} / \mathrm{ml} \mathrm{hCG}$ for $20 \mathrm{~min}$ at $37^{\circ} \mathrm{C}$. As shown in Fig. 3A and $\mathrm{B}$, VUF did not modify the basal cAMP levels but induced a significant decrease in LH/hCG-stimulated cAMP production. In order to determine whether the observed effect of VUF on the LH/hCG pathway was circumscribed to the inhibition of cAMP production, MA-10 cells were incubated with the membrane-
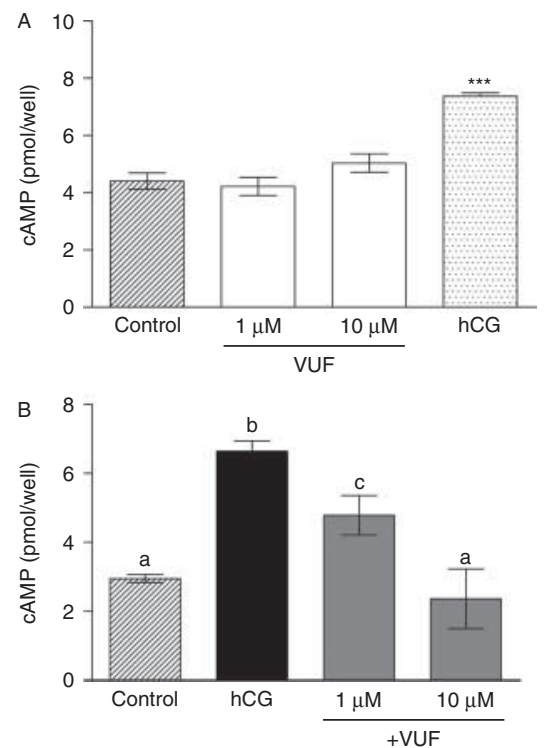

Figure 3

Effect of VUF on basal and hCG-stimulated cAMP production in MA-10 cells. The cells were incubated with 1 or $10 \mu \mathrm{M}$ VUF, in the absence $(A)$ or presence (B) of $40 \mathrm{ng} / \mathrm{ml} \mathrm{hCG}$, for $20 \mathrm{~min}$. Intracellular cAMP levels were measured as described in 'Materials and methods' section. Scale bars are means \pm s.E.M. for a representative $(n=3)$ triplicate experiment.

$* * * P<0.001$ vs Control. Different letters above the bars indicate that the groups differ significantly at $P<0.01$.

Published by Bioscientifica Ltd. 


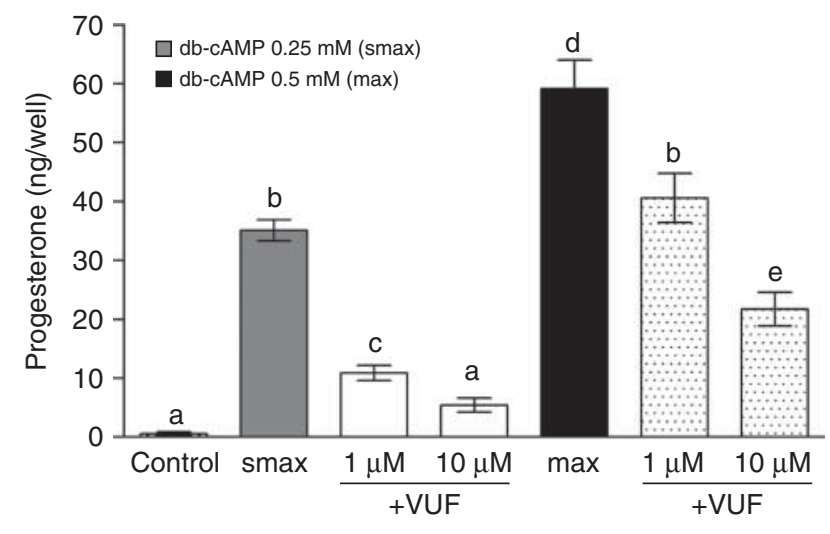

Figure 4

Effect of VUF on db-cAMP-stimulated progesterone production in MA-10 cells. The cells were incubated with 1 or $10 \mu \mathrm{M}$ VUF, in the presence of $0.25 \mathrm{mM}$ (smax) or $0.5 \mathrm{mM}$ (max) db-CAMP, for $5 \mathrm{~h}$. Scale bars are means \pm s.E.M. for a representative $(n=3)$ triplicate experiment. Different letters above the bars indicate that the groups differ significantly at $P<0.05$.

permeable analog of cAMP, db-cAMP, at a submaximal concentration $(0.25 \mathrm{mM})$, in the absence or presence of 1 or $10 \mu \mathrm{M}$ VUF for $5 \mathrm{~h}$ at $37^{\circ} \mathrm{C}$. It is shown in Fig. 4 that VUF potently inhibited progesterone production stimulated by the nucleotide ( $84 \%$ inhibition for $10 \mu \mathrm{M}$ VUF, on average). Similar results were obtained in the presence of a maximal db-cAMP concentration $(0.5 \mathrm{mM})$, although the percentage inhibition was lower (64\% inhibition for $10 \mu \mathrm{M}$ VUF, on average, Fig. 4). To further identify the post-cAMP site(s) of VUF action, we examined the effect of the agonist on the expression of the StAR protein, which mediates the rate-limiting step in steroid hormone biosynthesis (i.e. the delivery of cholesterol from the outer to the inner mitochondrial membrane; Stocco \& Clark 1996). As shown in Fig. 5, treatment of MA-10 cells with $10 \mu \mathrm{M}$ VUF caused a marked reduction in both hCG and db-cAMP-stimulated StAR protein expression.

\section{HRH4 activation inhibits MA-10 Leydig cell proliferation}

It is well established that HA plays a role as a modulator of cell proliferation in the most diverse experimental models, including MA-10 cells (Falus et al. 2011, Pagotto et al. 2012, 2014). Thus, to evaluate the possible effect of HRH4 activation on MA-10 cell proliferation, the cells were incubated with increasing concentrations (1 nM$10 \mu \mathrm{M})$ of VUF for $24 \mathrm{~h}$, and $\left[{ }^{3} \mathrm{H}\right]$-thymidine incorporation was determined. Interestingly, as shown in Fig. 6A, VUF inhibited MA-10 cell proliferation in a concentrationdependent manner, with a maximum effect observed in the presence of $10 \mu \mathrm{M}$ VUF (67\% inhibition, on average).
Consistent results were obtained when assessing cell proliferation indirectly with the MTS colorimetric assay (Fig. 6B).

\section{Lack of effect of a HRH3 agonist on MA-10 Leydig cell steroidogenesis and proliferation}

HRH4 shares the highest sequence homology with HRH3 (Medina \& Rivera 2010). Thus, given that VUF has been reported to display moderate affinity for HRH3 in certain cell types (Lim et al. 2009) and taking into account a previous study reported by Lovenberg et al. (1999) suggesting testicular expression of HRH3, we decided to evaluate the effect of R- $\alpha$, a HRH3 agonist, on steroidogenesis and proliferation in MA-10 cells, to confirm that the observed effects of VUF did not involve HRH3 activation. Firstly, MA-10 cells were incubated with increasing concentrations of $\mathrm{R}-\alpha(1 \mathrm{nM}-10 \mu \mathrm{M})$, in the absence or presence of $40 \mathrm{ng} / \mathrm{ml} \mathrm{hCG}$, for $5 \mathrm{~h}$. As can be seen in Fig. 7A and B, R- $\alpha$ had no significant effect on either basal or hCG-induced steroid production. In subsequent experiments, the cells were incubated

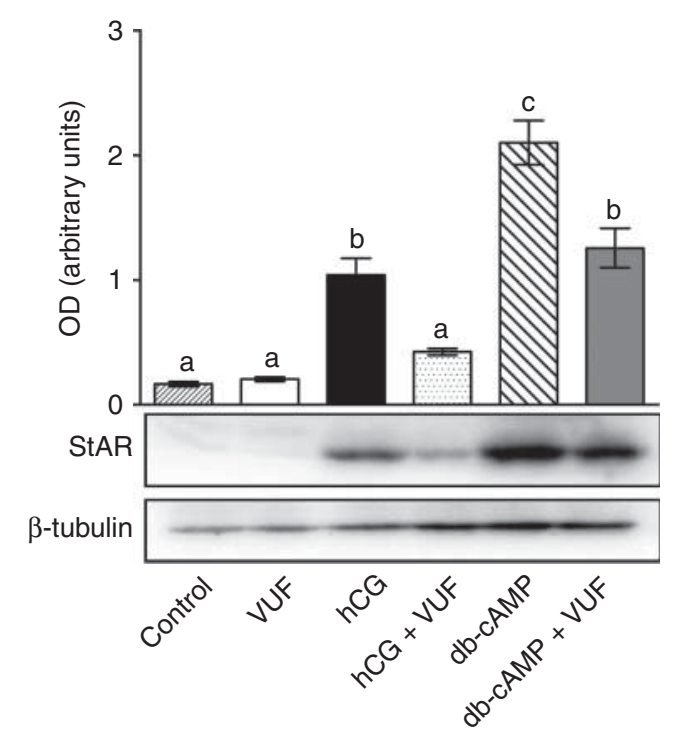

\section{Figure 5}

Effect of VUF on StAR protein levels. The cells were incubated with $10 \mu \mathrm{M}$ VUF, in the absence or presence of $40 \mathrm{ng} / \mathrm{ml} \mathrm{hCG}$ or $0.5 \mathrm{mM} \mathrm{db}-\mathrm{cAMP}$, for $5 \mathrm{~h}$. After treatments, the cells were lysed and subjected to western blotting analysis as described in 'Materials and methods' section. Data were normalized to the $55-\mathrm{kDa}$ internal control $\beta$-tubulin. A representative western blotting of StAR protein is shown, together with the quantitation of protein levels by scanning densitometry. Each bar shows the mean \pm S.E.M. of three independent experiments performed with triplicate samples. Different letters above the bars indicate that the groups differ significantly at $P<0.05$. 

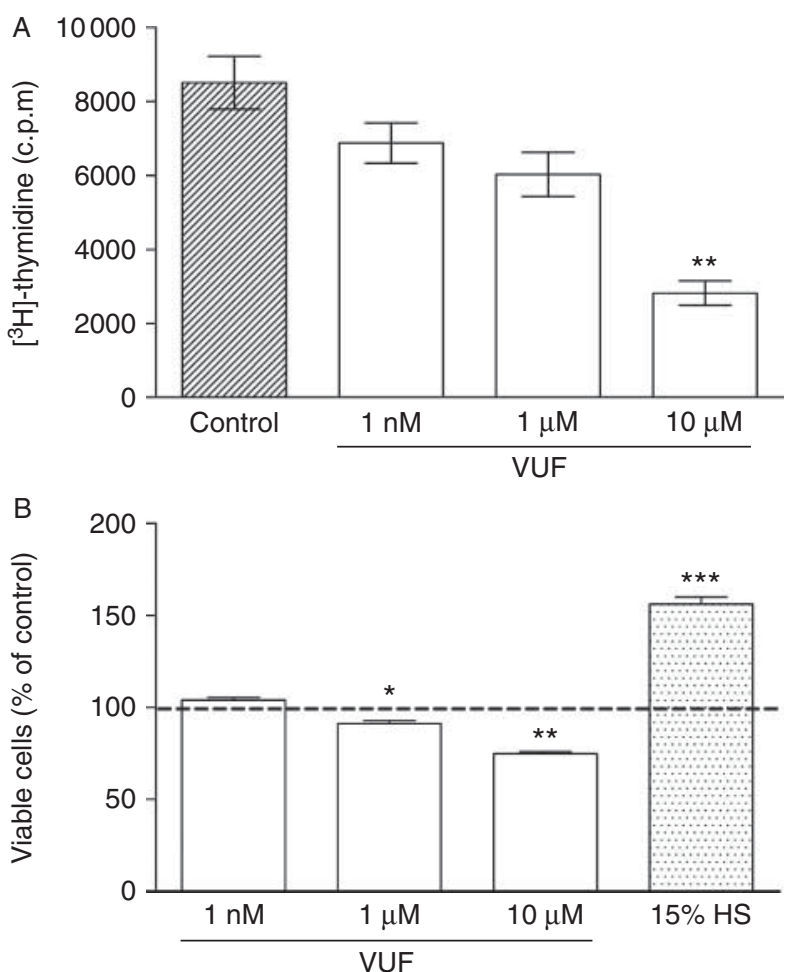

Figure 6

Effect of VUF on MA-10 cell proliferation. (A) MA-10 cells were incubated with increasing concentrations of VUF $(1 \mathrm{nM}-10 \mu \mathrm{M})$ for $24 \mathrm{~h}$. The cells were labeled with $\left[{ }^{3} \mathrm{H}\right]$-thymidine during the last $4 \mathrm{~h}$ of this incubation, and the radioactivity incorporated into DNA was measured as described in 'Materials and methods' section. Scale bars are means \pm s.E.M. for a representative $(n=3)$ octuplicate experiment. ${ }^{* *} P<0.01$ vs Control. (B) MA-10 cells were incubated with VUF $(1 \mathrm{nM}-10 \mu \mathrm{M})$ for $24 \mathrm{~h}$ as indicated. MTS reagent $(20 \mu \mathrm{l} /$ well) was then added, and the OD at $490 \mathrm{~nm}$ was recorded after $1 \mathrm{~h}$ of incubation at $37^{\circ} \mathrm{C}$ using a microplate reader. The percentage of viable cells is shown. Scale bars are means \pm s.E.M. for a representative $(n=3)$ octuplicate experiment. ${ }^{*} P<0.05$ vs Control, $* * P<0.01$ vs Control, and $* * * P<0.001$ vs Control. Horse serum at $15 \%$ $(15 \% \mathrm{HS})$ was used as a positive control.

with increasing concentrations $(1 \mathrm{nM}-10 \mu \mathrm{M})$ of $\mathrm{R}-\alpha$ for $24 \mathrm{~h}$, and $\left[{ }^{3} \mathrm{H}\right]$-thymidine incorporation was determined. As shown in Fig. 7C, R- $\alpha$ had no effect on MA-10 cell proliferation at any tested concentration.

\section{HRH4 agonists inhibit normal rat Leydig cell proliferation}

We previously demonstrated that tumor MA-10 cells behave in a similar manner to their normal equivalent in terms of HA-induced regulation of acute steroidogenesis (Mondillo et al. 2005, 2009), while they respond differently to HA when it comes to cell proliferation (Khan \& Rai 2007, Pagotto et al. 2012). Thus, to evaluate whether the observed effect of HRH4 agonists on the proliferation of MA-10 cells could be extrapolated to their normal
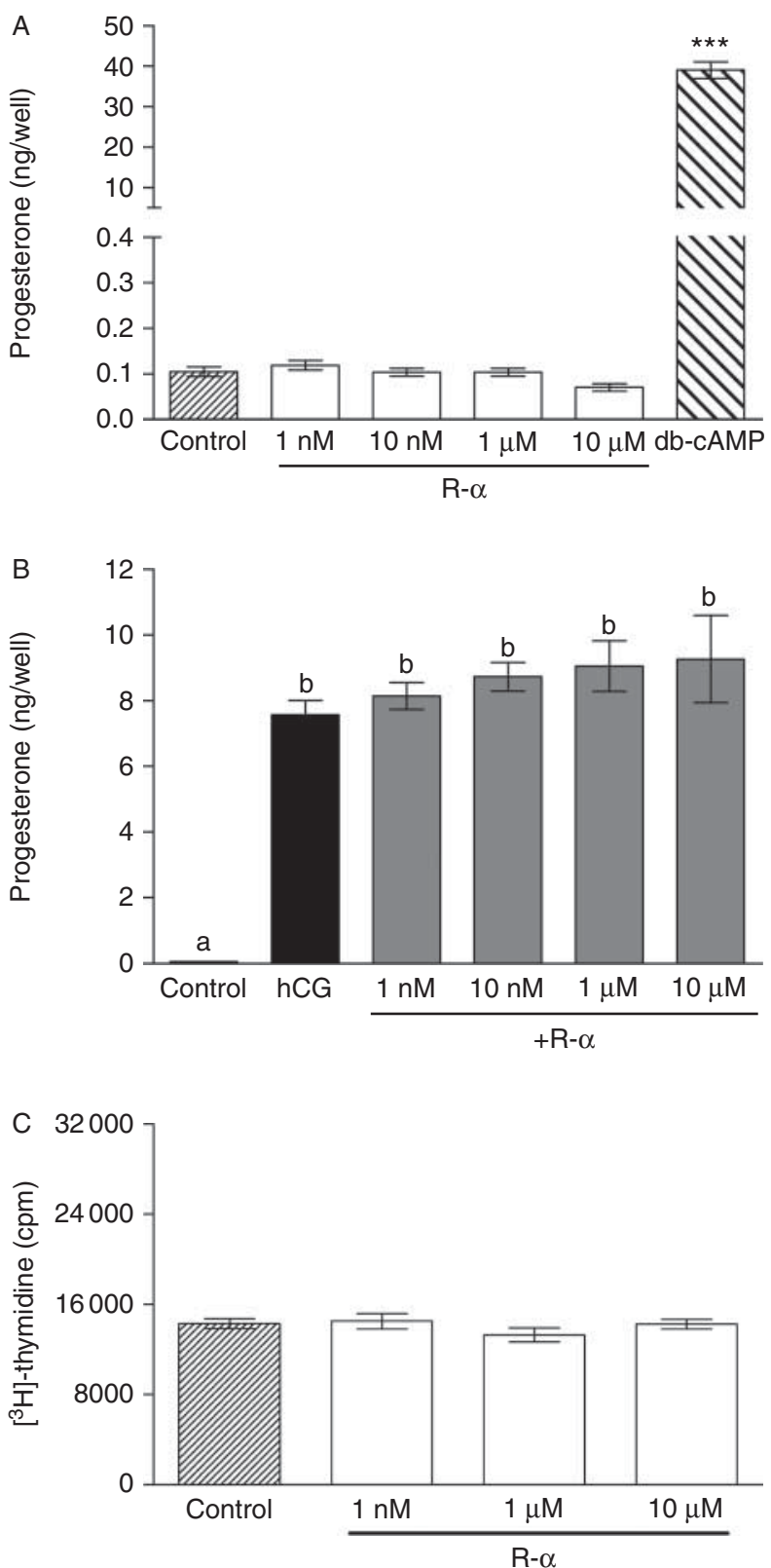

Figure 7

Effect of an HRH3 agonist on basal and hCG-stimulated progesterone production in MA-10 cells and on MA-10 cell proliferation. The cells were incubated with increasing concentrations $(1 \mathrm{nM}-10 \mu \mathrm{M})$ of the HRH3 agonist R- $\alpha$, in the absence (A) or presence (B) of $40 \mathrm{ng} / \mathrm{ml} \mathrm{hCG,} \mathrm{for} 5 \mathrm{~h}$. Scale bars are means \pm S.E.M. for a representative $(n=3)$ triplicate experiment. ${ }^{* *} P<0.001$ vs Control. Different letters above the bars indicate that the groups differ significantly at $P<0.01$. In subsequent experiments, cells were incubated with increasing concentrations of $\mathrm{R}-\alpha$ $(1 \mathrm{nM}-10 \mu \mathrm{M})$ for $24 \mathrm{~h}(\mathrm{C})$. The cells were labeled with $\left[{ }^{3} \mathrm{H}\right]$-thymidine during the last $4 \mathrm{~h}$ of this incubation, and the radioactivity incorporated into DNA was measured as described in 'Materials and methods' section. Scale bars are means \pm S.E.M. for a representative $(n=3)$ octuplicate experiment. No significant differences were observed between control and treated cells at any $\mathrm{R}-\alpha$ concentration evaluated. 

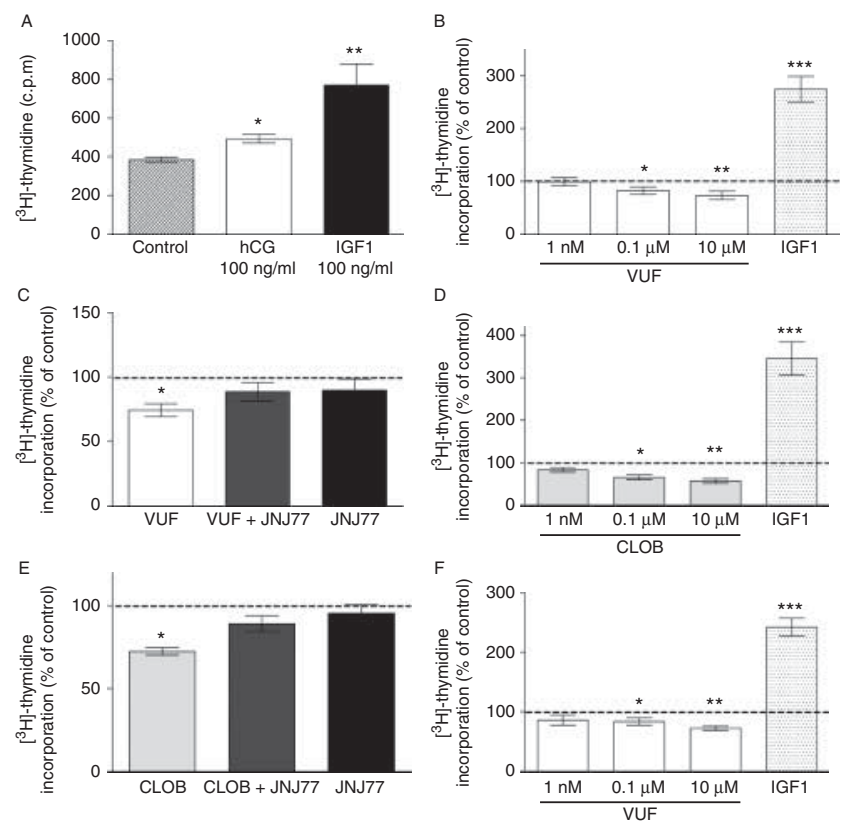

Figure 8

(A) Effects of hCG and IGF1 on ILC proliferation. ILCs were incubated with $100 \mathrm{ng} / \mathrm{ml} \mathrm{hCG}$ or $100 \mathrm{ng} / \mathrm{ml}$ IGF1 for $24 \mathrm{~h}$ as indicated. The cells were labeled with $\left[{ }^{3} \mathrm{H}\right]$-thymidine during the last $16 \mathrm{~h}$ of this incubation, and the radioactivity incorporated into DNA was measured as described in 'Materials and methods' section. Each bar is the mean \pm s.E.M. of three independent experiments. ${ }^{*} P<0.05$ vs control and $* * P<0.01$ vs control. (B) Effect of VUF on ILC cell proliferation. ILCs were incubated with increasing concentrations of VUF $(1 \mathrm{nM}-10 \mu \mathrm{M})$ or $100 \mathrm{ng} / \mathrm{ml}$ IGF1 for $24 \mathrm{~h}$ as indicated. The cells were labeled with $\left[{ }^{3} \mathrm{H}\right]$-thymidine during the last $16 \mathrm{~h}$ of this incubation, and the radioactivity incorporated into DNA was measured as described in 'Materials and methods' section. Each bar is the mean \pm S.E.M. of three independent experiments. ${ }^{*} P<0.05$ vs control; $* * P<0.01$ vs control; and $* * * P<0.001$ vs control. (C) Effect of JNJ77 on VUF-mediated inhibition of ILCs proliferation. ILCs were pre-incubated with or without $1 \mu \mathrm{M}$ JNJ77 for $30 \mathrm{~min}$, and then incubated with or without $10 \mu \mathrm{M}$ VUF for $24 \mathrm{~h}$ as indicated. The cells were labeled with $\left[{ }^{3} \mathrm{H}\right]$-thymidine during the last $16 \mathrm{~h}$ of this incubation, and the radioactivity incorporated into DNA was measured as described in 'Materials and methods' section. Each bar is the mean \pm s.E.M. of three independent experiments. $* P<0.05$ vs control. (D) Effect of CLOB on ILC cell proliferation. ILCs were incubated with increasing concentrations of CLOB $(1 \mathrm{nM}-10 \mu \mathrm{M})$ or $100 \mathrm{ng} / \mathrm{ml} \mathrm{IGF1}$ for $24 \mathrm{~h}$ as indicated. The cells were labeled with $\left[{ }^{3} \mathrm{H}\right]-$ thymidine during the last $16 \mathrm{~h}$ of this incubation, and the radioactivity incorporated into DNA was measured as described in 'Materials and methods' section. Each bar is the mean \pm S.E.M. of three independent experiments. $\star P<0.05$ vs control; $* * P<0.01$ vs control; and $* * * P<0.001$ vs control. (E) Effect of JNJ77 on CLOB-mediated inhibition of ILCs proliferation. ILCs were pre-incubated with or without $1 \mu \mathrm{M}$ JNJ77 for $30 \mathrm{~min}$, and then incubated with or without $10 \mu \mathrm{M}$ CLOB for $24 \mathrm{~h}$ as indicated. The cells were labeled with $\left[{ }^{3} \mathrm{H}\right]$-thymidine during the last $16 \mathrm{~h}$ of this incubation, and the radioactivity incorporated into DNA was measured as described in 'Materials and methods' section. Each bar is the mean \pm s.E.M. of three independent experiments. ${ }^{*} P<0.05$ vs control. (F) Effect of VUF on PLC cell proliferation. PLCs were incubated with increasing concentrations of VUF $(1 \mathrm{nM}-10 \mu \mathrm{M})$ or $100 \mathrm{ng} / \mathrm{ml}$ IGF1 for $24 \mathrm{~h}$ as indicated. The cells were labeled with [ $\left.{ }^{3} \mathrm{H}\right]-$ thymidine during the last $16 \mathrm{~h}$ of this incubation, and the radioactivity incorporated into DNA was measured as described in 'Materials and methods' section. Each bar is the mean \pm S.E.M. of three independent experiments. $* P<0.05$ vs control; $* * P<0.01$ vs control; and $* * * P<0.001$ vs control. counterpart, and taking into account that adult Leydig cells present minimal proliferative capacity (Chen et al. 2010), we carried out a series of experiments using a proliferating population of immature rat Leydig cells (ILCs) in culture, isolated from 35-day-old rats as described in 'Materials and methods' section. ILCs were incubated with either $100 \mathrm{ng} / \mathrm{ml} \mathrm{hCG}, 100 \mathrm{ng} / \mathrm{ml} \mathrm{IGF1}$, or increasing concentrations of VUF $(1 \mathrm{nM}-10 \mu \mathrm{M})$ for $24 \mathrm{~h}$, and $\left[{ }^{3} \mathrm{H}\right]$-thymidine incorporation was determined. As expected, both hCG and IGF1 promoted ILC proliferation significantly (Fig. 8A). In contrast, VUF exhibited an antiproliferative action (Fig. 8B), which was antagonized by previous incubation of the cells with the HRH4 antagonist JNJ77 (Fig. 8C). Similar results were obtained with CLOB, another HRH4 agonist (Fig. 8D and E). Finally, we carried out proliferation experiments using progenitor rat Leydig cells (PLCs) isolated from 18- to 20-day-old rat testes as described in 'Materials and methods' section. Again, VUF inhibited cell proliferation (Fig. 8F).

\section{Detection of HRH4 in normal rat testis by immunohistochemistry}

To complement the aforementioned findings and in view of the very limited information available in the literature regarding the expression of HRH4 within the male gonad, we searched for the expression sites of HRH4 in testis sections of rats, ranging from 7 to 240 days of age. As shown in Fig. 9, positive HRH4 immunostaining was detected in Leydig cells of all testicular sections evaluated. Interestingly, in testis sections of 21-day-old rats, HRH4 staining was not only circumscribed to Leydig cells but was also detected within the seminiferous tubules, in male gametes.

\section{Discussion}

The discovery of HRH4 at the turn of the millenium renewed the interest in HA receptor pharmacology and led to a substantial rise in HRH4-related papers and patents in the last few years (Leurs et al. 2009, Schreeb et al. 2013). Although HRH4 shows preferential distribution in cells of immunological relevance, such as T-cells, dendritic cells, monocytes, mast cells, and neutrophils (Medina \& Rivera 2010), accumulating evidence indicates its functional expression in a variety of nonimmume tissues and cells, including intestinal epithelium, spleen, lung, stomach, CNS, nerves of nasal mucosa, enteric neurons, salivary glands, and even cancer cells (Nguyen et al. 2001, Connelly et al. 2009, Lethbridge \& Chazot 2010, Medina \& Rivera 2010, Stegaev et al. 2012), suggesting an extensive

Published by Bioscientifica Ltd 


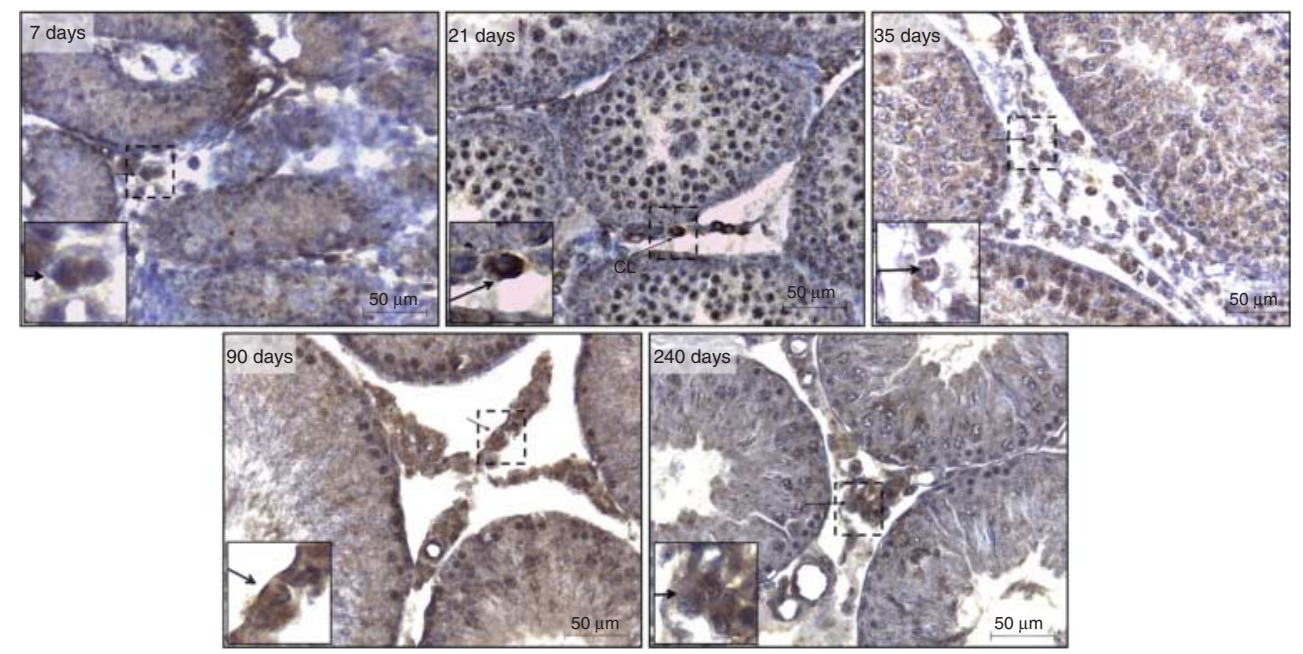

\section{Figure 9}

Evaluation of testicular HRH4 expression in rats of different ages. Immunohistochemistry for HRH4 was performed on Bouin-fixed paraffinembedded testis sections of rats at 7, 21, 35, 90, and 240 days of age. The arrows indicate HRH4-positive Leydig cells. Scale bars represent $50 \mu \mathrm{m}$.

biological role for this receptor subtype, which warrants further research. With specific regard to the male gonad, Nguyen et al. (2001) have documented the expression of Hrh4 mRNA in rat testicular homogenate and a study by O'Reilly et al. (2002) indicates low HRH4 levels in the human testis. However, neither a specific cell localization nor a role for HRH4 has been established so far. Herein, we describe for the first time that the expression of functional receptors $\mathrm{HRH} 4$ can significantly inhibit the steroidogenic action of LH/hCG in MA-10 Leydig cells, as demonstrated by a marked reduction in LH/hCG-induced progesterone levels in the presence of two different HRH4 agonists: VUF and JNJ286. On the basis of our findings, such reduction would involve the inhibition of LH/hCGstimulated cAMP production, a fact that is consistent with the extensive literature suggesting the coupling of $\mathrm{HRH} 4$ to a Gi protein (Leurs et al. 2009, Medina \& Rivera 2010, Jemima et al. 2014). Moreover, we show herein that HRH4 activation would also affect the LH/hCG steroidogenic action downstream of cAMP production, at the level of StAR protein expression. In a previous publication, we reported that the inhibitory effect of HA $10 \mu \mathrm{M}$ on LH/hCGinduced steroidogenesis in Leydig cells, mediated via HRH1 activation, decreased cAMP production and inhibition of StAR protein expression (Mondillo et al. 2009). However, based on our present findings, it is reasonable to assume that HRH4 would also be involved in the aforementioned inhibitory effect of HA on steroid synthesis. In line with this hypothesis, there is evidence of synergistic effects between
Inner boxes in each panel represent a threefold enlargement of the area inside the dashed rectangle. Representative images of three independent experiments are shown. A full colour version of this figure is available via http://dx.doi.org/10.1530/JOE-14-0401.

HRH1 and HRH4 in other cell types, in which HRH4 colocalizes with HRH1 (Thurmond et al. 2008, Deiteren et al. 2014). What is more, it has been suggested that HRH4 may be as important as HRH1 in the pathophysiology of allergic conditions such as conjunctivitis, and that these conditions should be treated with HRH1 and HRH4 antagonists simultaneously (Thurmond et al. 2008).

Previously, we reported that HA exerts a stimulatory effect on the proliferation of MA-10 cells, mediated via HRH2 activation and a transient increase in intracellular cAMP levels (Pagotto et al. 2012). At that time we found no anti-proliferative effect of HA at any concentration evaluated. However, it is shown herein that, in agreement with previous research by other authors in various cell types (Petit-Bertron et al. 2009, Medina et al. 2011), treatment of MA-10 cells with VUF significantly inhibits their proliferation. Generally speaking, the final effect of $\mathrm{HA}$ on a given target cell is mostly determined by the relative abundance of the different histaminergic receptor subtypes on its membrane, which in turn defines the signal transduction pathways that are ultimately activated (Mitsuhashi et al. 1989, Davio et al. 1995, Fitzsimons et al. 2002, Medina \& Rivera 2010). HRH4 seems to be expressed at moderate to low levels in most nonimmune cells and tissues (Stark 2007, Leurs et al. 2009, Medina \& Rivera 2010). Meanwhile, it has been reported that HRH2 expression is induced by HA in a tissue-specific manner (Fitzsimons et al. 2001), and a previous study by our group demonstrates that Leydig cells express the active

Published by Bioscientifica Ltd. 
form of HDC enzyme (Pagotto et al. 2012). Thus, it could be speculated that HRH2 outnumbers HRH4 on the membrane of MA-10 cells, implying that HA would predominantly act though HRH2, thereby stimulating cell proliferation. Clearly, this hypothesis requires further investigation.

HRH4 shows low degree of sequence homology with other HA receptors. Its closest member in the HA receptor family is HRH3 (37\% overall homology and 58\% in transmembrane regions; Medina \& Rivera 2010). Lovenberg et al. (1999) have reported low testicular HRH3 expression. However, we show herein that a specific HRH3 agonist had no effect on MA-10 cell steroidogenesis or proliferation. Thus, although VUF appears to display moderate affinity for HRH3 in certain cell types (Lim et al. 2009), it can be assumed, on the basis of our findings, that its effects on MA-10 cell function are due to HRH4 - and not HRH3 - activation.

Previous reports by our group and others indicate that, although MA-10 Leydig tumor cells and normal rat Leydig cells exhibit a similar steroidogenic response to HA (Mondillo et al. 2005, 2009, Khan \& Rai 2007), they behave differently when it comes to HA-induced regulation of cell proliferation (Khan \& Rai 2007, Pagotto et al. 2012). Indeed, HA does not seem to modulate the proliferation of normal PLCs or ILCs, at least in a physiological context (Pagotto et al. 2012). However, our present results demonstrate that both normal PLCs and ILCs are susceptible to the anti-proliferative action of HRH4 agonists. Also, we show herein that, in the normal rat testis, HRH4 expression in Leydig cells is detectable already by day 7 of age. Thus, although the precise testicular milieu under which HA would predominantly activate HRH4 remains to be studied, our results highlight the importance of designing selective therapeutic drugs targeting HRH4, to avoid potential unwanted side effects on Leydig cell functions. What is more, in testis sections of 21-day-old rats, HRH4 staining was not only circumscribed to Leydig cells but was also detected within the seminiferous tubules, in male gametes, revealing an additional testicular site of HRH4 expression with potential significance to spermatogenesis.

In agreement with our present findings, HRH4 expression has been recently detected in human steroidogenic adrenal cortex (Szabo et al. 2009) and in subsets of endocrine cells in the gastrointestinal tract (distinct from HRH3-containing cells) (Morini et al. 2008). However, the inhibitory effect of HRH4 activation on gonadotropinstimulated steroid synthesis appears to be steroidogenic tissue-specific, considering the most recent publication of our group, which describes the lack of effect of VUF on steroidogenesis in two adrenocortical cell lines: murine Y1 cells and human NCI-H295R cells (Pagotto et al. 2014). Accordingly, in those cells HA did not modify basal or adrenocorticotropic hormone-induced steroid synthesis, although it did inhibit NCI-H295R cell proliferation via HRH1 (Pagotto et al. 2014). In view of these facts and previous studies by our group and others, it seems clear that research results regarding histaminergic regulation of Leydig cell function cannot be directly extrapolated to adrenocortical cells. Thereby, the functional significance of adrenal HRH4 expression remains to be clarified.

Given the importance of HA in human (patho) physiology, continued efforts are directed at the comprehensive elucidation of the emerging properties of HRH4 and its ligands (Schreeb et al. 2013). To the best of our knowledge, this study is the first to shed some light on the unresolved question regarding the specific cell localization and function of testicular HRH4. We hope that these results will help to expand our understanding of HRH4 pharmacology, and contribute to the development, optimization, and validation of more beneficial HRH4 targeting compounds aiming to enter clinical trials.

\section{Declaration of interest}

The authors declare that there is no conflict of interest that could be perceived as prejudicing the impartiality of the research reported.

\section{Funding}

This investigation was supported by grants from the Agencia Nacional de Promoción Científica y Tecnológica (ANPCYT, PICT 2012 No. 2776) and the Alberto J Roemmers Foundation to $C M$, and grants from the Consejo Nacional de Investigaciones Científicas y Técnicas (CONICET, PIP 382), and the University of Buenos Aires (UBA, UBACYT 2010-20020090100060 and 2013-20020120100205) to O P P.

\section{Acknowledgements}

The authors would like to thank Dr Ramiro Vázquez for help with figure design and critical reading of the manuscript.

\section{References}

Abramoff M, Magelhaes P \& Ram S 2004 Image processing with Image J. Biophotonics International 11 36-42.

Akdis CA \& Simons FE 2006 Histamine receptors are hot in immunopharmacology. European Journal of Pharmacology 533 69-76. (doi:10.1016/j.ejphar.2005.12.044)

Albrecht M, Frungieri MB, Gonzalez-Calvar S, Meineke V, Kohn FM \& Mayerhofer A 2005 Evidence for a histaminergic system in the human testis. Fertility and Sterility 83 1060-1063. (doi:10.1016/j.fertnstert. 2004.12.002) http://joe.endocrinology-journals.org DOI: 10.1530/JOE-14-0401
C) 2014 Society for Endocrinology Printed in Great Britain
Published by Bioscientifica Ltd 
Ascoli M 1981 Characterization of several clonal lines of cultured Leydig tumor cells: gonadotropin receptors and steroidogenic responses. Endocrinology 108 88-95. (doi:10.1210/endo-108-1-88)

Bongers G, de Esch I \& Leurs R 2010 Molecular pharmacology of the four histamine receptors. Advances in Experimental Medicine and Biology 709 11-19. (doi:10.1007/978-1-4419-8056-4_2)

Cara AM, Lopes-Martins RA, Antunes E, Nahoum CR \& De Nucci G 1995 The role of histamine in human penile erection. British Journal of Urology 75 220-224. (doi:10.1111/j.1464-410X.1995.tb07315.x)

Chen H, Stanley E, Jin S \& Zirkin BR 2010 Stem Leydig cells: from fetal to aged animals. Birth Defects Research. Part C, Embryo Today: Reviews 90 272-283. (doi:10.1002/bdrc.20192)

Connelly WM, Shenton FC, Lethbridge N, Leurs R, Waldvogel HJ, Faull RL, Lees G \& Chazot PL 2009 The histamine H4 receptor is functionally expressed on neurons in the mammalian CNS. British Journal of Pharmacology 157 55-63. (doi:10.1111/j.1476-5381.2009.00227.x)

Dale HH \& Laidlaw PP 1910 The physiological action of $\beta$-iminazolylethylamine. Journal of Physiology 41 318-344.

Davio CA, Cricco GP, Bergoc RM \& Rivera ES 1995 H1 and H2 histamine receptors in $\mathrm{N}$-nitroso- $\mathrm{N}$-methylurea (NMU)-induced carcinomas with atypical coupling to signal transducers. Biochemical Pharmacology 50 91-96. (doi:10.1016/0006-2952(95)00108-C)

Deiteren A, De Man JG, Ruyssers NE, Moreels TG, Pelckmans PA \& De Winter BY 2014 Histamine H4 and H1 receptors contribute to postinflammatory visceral hypersensitivity. Gut 2014 [in press]. (doi:10.1136/gutjnl-2013-305870)

Falus A, Pos Z \& Darvas Z 2011 Histamine in normal and malignant cell proliferation. Advances in Experimental Medicine and Biology $\mathbf{7 0 9}$ 109-123. (doi:10.1007/978-1-4419-8056-4_11)

Fitzsimons CP, Lazar-Molnar E, Tomoskozi Z, Buzas E, Rivera ES \& Falus A 2001 Histamine deficiency induces tissue-specific down-regulation of histamine $\mathrm{H} 2$ receptor expression in histidine decarboxylase knockout mice. FEBS Letters 508 245-248. (doi:10.1016/S0014-5793(01)03070-8)

Fitzsimons C, Engel N, Policastro L, Duran H, Molinari B \& Rivera E 2002 Regulation of phospholipase $\mathrm{C}$ activation by the number of $\mathrm{H}(2)$ receptors during $\mathrm{Ca}(2+)$-induced differentiation of mouse keratinocytes. Biochemical Pharmacology 63 1785-1796. (doi:10.1016/ S0006-2952(02)00975-9)

Garnier M, Boujrad N, Oke BO, Brown AS, Riond J, Ferrara P, Shoyab M, Suarez-Quian CA \& Papadopoulos V 1993 Diazepam binding inhibitor is a paracrine/autocrine regulator of Leydig cell proliferation and steroidogenesis: action via peripheral-type benzodiazepine receptor and independent mechanisms. Endocrinology 132 444-458. (doi:10. 1210/endo.132.1.8380386)

Jemima EA, Prema A \& Thangam EB 2014 Functional characterization of histamine $\mathrm{H} 4$ receptor on human mast cells. Molecular Immunology 62 19-28. (doi:10.1016/j.molimm.2014.05.007)

Khan UW \& Rai U 2007 Differential effects of histamine on Leydig cell and testicular macrophage activities in wall lizards: precise role of $\mathrm{H} 1 / \mathrm{H} 2$ receptor subtypes. Journal of Endocrinology 194 441-448. (doi:10.1677/ JOE-06-0225)

Lethbridge NL \& Chazot PLx 2010 Immunological identification of the mouse $\mathrm{H} 4$ histamine receptor on spinal cord motor neurons using a novel anti-mouse H4R antibody. Inflammation Research 59 (Suppl 2) S197-S198. (doi:10.1007/s00011-009-0127-2)

Leurs R, Chazot PL, Shenton FC, Lim HD \& de Esch IJ 2009 Molecular and biochemical pharmacology of the histamine $\mathrm{H} 4$ receptor. British Journal of Pharmacology 157 14-23. (doi:10.1111/j.1476-5381.2009. 00250.x)

Lim HD, Adami M, Guaita E, Werfel T, Smits RA, de Esch IJ, Bakker RA, Gutzmer R, Coruzzi G \& Leurs R 2009 Pharmacological characterization of the new histamine H4 receptor agonist VUF 8430. British Journal of Pharmacology 157 34-43. (doi:10.1111/j.1476-5381.2009.00200.x)

Lovenberg TW, Roland BL, Wilson SJ, Jiang X, Pyati J, Huvar A, Jackson MR \& Erlander MG 1999 Cloning and functional expression of the human histamine H3 receptor. Molecular Pharmacology 55 1101-1107. (doi:10. 1124/mol.55.6.1101)

Mayerhofer A, Bartke A, Amador AG \& Began T 1989 Histamine affects testicular steroid production in the golden hamster. Endocrinology 125 2212-2214. (doi:10.1210/endo-125-4-2212)

Medina VA \& Rivera ES 2010 Histamine receptors and cancer pharmacology. British Journal of Pharmacology 161 755-767. (doi:10.1111/ j.1476-5381.2010.00961.x)

Medina VA, Brenzoni PG, Lamas DJ, Massari N, Mondillo C, Nunez MA, Pignataro O \& Rivera ES 2011 Role of histamine H4 receptor in breast cancer cell proliferation. Frontiers in Bioscience 3 1042-1060.

Mitsuhashi M, Mitsuhashi T \& Payan DG 1989 Multiple signaling pathways of histamine $\mathrm{H} 2$ receptors. Identification of an $\mathrm{H} 2$ receptor-dependent $\mathrm{Ca}^{2+}$ mobilization pathway in human HL-60 promyelocytic leukemia cells. Journal of Biological Chemistry 264 18356-18362.

Mondillo C, Patrignani Z, Reche C, Rivera E \& Pignataro O 2005 Dual role of histamine in modulation of Leydig cell steroidogenesis via HRH1 and HRH2 receptor subtypes. Biology of Reproduction 73 899-907. (doi:10.1095/biolreprod.105.041285)

Mondillo C, Falus A, Pignataro O \& Pap E 2007 Prolonged histamine deficiency in histidine decarboxylase gene knockout mice affects Leydig cell function. Journal of Andrology 28 86-91. (doi:10.2164/ jandrol.106.000257)

Mondillo C, Pagotto RM, Piotrkowski B, Reche CG, Patrignani ZJ, Cymeryng CB \& Pignataro OP 2009 Involvement of nitric oxide synthase in the mechanism of histamine-induced inhibition of Leydig cell steroidogenesis via histamine receptor subtypes in Sprague-Dawley rats. Biology of Reproduction 80 144-152. (doi:10.1095/biolreprod.108.069484)

Morini G, Becchi G, Shenton FC, Chazot PL \& Grandi D 2008 Histamine H3 and $\mathrm{H} 4$ receptors are expressed on distinct endocrine cell types in the rat fundic mucosa. Inflammation Research 57(Suppl 1) S57-S58. (doi:10.1007/s00011-007-0628-9)

Morse KL, Behan J, Laz TM, West RE Jr, Greenfeder SA, Anthes JC, Umland S, Wan Y, Hipkin RW, Gonsiorek W et al. 2001 Cloning and characterization of a novel human histamine receptor. Journal of Pharmacology and Experimental Therapeutics 296 1058-1066.

Nemetallah BR, Howell RE \& Ellis LC 1983 Histamine H1 receptors and prostaglandin-histamine interactions modulating contractility of rabbit and rat testicular capsules in vitro. Biology of Reproduction $\mathbf{2 8}$ 632-635. (doi:10.1095/biolreprod28.3.632)

Nguyen T, Shapiro DA, George SR, Setola V, Lee DK, Cheng R, Rauser L, Lee SP, Lynch KR, Roth BL et al. 2001 Discovery of a novel member of the histamine receptor family. Molecular Pharmacology 59 427-433. (doi:10.1124/mol.59.3.427)

Ohtsu H 2010 Histamine synthesis and lessons learned from histidine decarboxylase deficient mice. Advances in Experimental Medicine and Biology 709 21-31. (doi:10.1007/978-1-4419-8056-4_3)

O'Reilly M, Alpert R, Jenkinson S, Gladue RP, Foo S, Trim S, Peter B, Trevethick M \& Fidock M 2002 Identification of a histamine H4 receptor on human eosinophils - role in eosinophil chemotaxis. Journal of Receptors and Signal Transduction Research 22 431-448. (doi:10.1081/RRS-120014612)

Pagotto RM, Monzon C, Moreno MB, Pignataro OP \& Mondillo C 2012 Proliferative effect of histamine on MA-10 Leydig tumor cells mediated through HRH2 activation, transient elevation in cAMP production, and increased extracellular signal-regulated kinase phosphorylation levels. Biology of Reproduction 87 150. (doi:10.1095/biolreprod.112.102905)

Pagotto RM, Pereyra EN, Monzon C, Mondillo C \& Pignataro OP 2014 Histamine inhibits adrenocortical cell proliferation but does not affect steroidogenesis. Journal of Endocrinology 221 15-28. (doi:10.1530/ JOE-13-0433)

Par G, Szekeres-Bartho J, Buzas E, Pap E \& Falus A 2003 Impaired reproduction of histamine deficient (histidine-decarboxylase knockout) mice is caused predominantly by a decreased male mating behavior. American Journal of Reproductive Immunology $\mathbf{5 0}$ 152-158. (doi:10.1034/j.1600-0897.2003.00066.x) 
Parsons ME \& Ganellin CR 2006 Histamine and its receptors. British Journal of Pharmacology 147(Suppl 1) S127-S135. (doi:10.1038/sj.bjp. 0706440)

Petit-Bertron AF, Machavoine F, Defresne MP, Gillard M, Chatelain P, Mistry P, Schneider E \& Dy M 2009 H4 histamine receptors mediate cell cycle arrest in growth factor-induced murine and human hematopoietic progenitor cells. PLoS ONE 4 e6504. (doi:10.1371/journal.pone.0006504)

Piroli G, Pignataro O \& De Nicola AF 1992 Increased activity of type I regulatory subunit of cyclic adenosine $3^{\prime}, 5^{\prime}$-monophosphate-dependent protein kinase in estrogen-induced pituitary tumors. Journal of the National Cancer Institute 84 1565-1571. (doi:10.1093/jnci/84.20.1565)

Safina F, Tanaka S, Inagaki M, Tsuboi K, Sugimoto Y \& Ichikawa A 2002 Expression of L-histidine decarboxylase in mouse male germ cells. Journal of Biological Chemistry 277 14211-14215. (doi:10.1074/jbc. M200702200)

Schreeb A, Łażewska D, Dove S, Buschauer A, Kieć-Kononowicz K \& Stark H 2013 Histamine H4 receptor ligands. In Histamine H4 Receptor: A Novel Drug Target in Immunoregulation and Inflammation, pp 21-62. Ed H Stark. London: Versita.

Shahid M, Tripathi T, Khan R, Khardori N, Al-Sultan A, AL-Mohammed H, Alsultan A, Huq A, Khan A \& Siddiqui M 2011 Biological and pharmacological aspects of histamine receptors and their ligands. In Biomedical Aspects of Histamine, pp 61-100. Eds N Khardori, R Khan \& $\mathrm{T}$ Tripathi. The Netherlands: Springer.
Sinha RB, Banerjee P \& Ganguly AK 2006 Serum concentration of testosterone, epididymal mast cell population and histamine content in relation to sperm count and their motility in albino rats following $\mathrm{H} 2$ receptor blocker treatment. Nepal Medical College Journal 8 36-39.

Stark H 2007 Histamine receptors. Biotrend Reviews 1 1-9.

Stegaev V, Sillat T, Porola P, Hanninen A, Falus A, Mieliauskaite D, Buzas E, Rotar Z, Mackiewicz Z, Stark H et al. 2012 Brief report: first identification of $\mathrm{H}(4)$ histamine receptor in healthy salivary glands and in focal sialadenitis in Sjogren's syndrome. Arthritis and Rheumatism 64 2663-2668. (doi:10.1002/art.34484)

Steiner AL, Kipnis DM, Utiger R \& Parker C 1969 Radioimmunoassay for the measurement of adenosine $3^{\prime}, 5^{\prime}$-cyclic phosphate. PNAS $64367-373$. (doi:10.1073/pnas.64.1.367)

Stocco DM \& Clark BJ 1996 Regulation of the acute production of steroids in steroidogenic cells. Endocrine Reviews 17 221-244. (doi:10.1210/edrv17-3-221)

Szabo PM, Wiener Z, Tombol Z, Kovacs A, Pocza P, Horanyi J, Kulka J, Riesz P, Toth M, Patocs A et al. 2009 Differences in the expression of histaminerelated genes and proteins in normal human adrenal cortex and adrenocortical tumors. Virchows Archiv 455 133-142. (doi:10.1007/ s00428-009-0807-x)

Thurmond RL, Gelfand EW \& Dunford PJ 2008 The role of histamine H1 and $\mathrm{H} 4$ receptors in allergic inflammation: the search for new antihistamines. Nature Reviews. Drug Discovery 7 41-53. (doi:10.1038/nrd2465)

Received in final form 16 September 2014

Accepted 24 September 2014

Accepted Preprint published online 24 September 2014
(C) 2014 Society for Endocrinology Printed in Great Britain 